\title{
Trust in leadership and incentives: Experimental study of whistleblowing intention
}

\author{
Ema Yulianing Tyas, Intiyas Utami* \\ Faculty of Economics and Business, Universitas Kristen Satya Wacana, Salatiga, Indonesia \\ *Corresponding author email: intiyas@staff.uksw.edu
}

A R T I C LE IN F O

Article history:

Available online

Keywords:

Trust in leadership, incentive, and whistleblowing intentions

DOI:

https://doi.org/10.20885/jaai.vol24.is $\underline{\text { s1.art5 }}$

\author{
A B S T R A C T
}

Whistleblowing is a disclosure act made by members of organization related to illegal practices of the organization. Trust in leadership and incentive is related to whistleblowing intention and has become a consideration for a whistleblower in conducting his/her whistleblowing actions. When an employee knows the existence of fraud, he can report the fraud to the leaders of his company when he believes that the leaders of his company can eradicate that fraud. This study was accounting undergraduate students as subjects. This study was aimed to examine the potential of employees' whistleblowing intentions in the existence of trust toward their leaders and in the existence of incentives. This study used an experimental design of $2 \times 2$ between subjects. The treatments were given in the form of trust in leadership (high and low level of leadership) and incentives (existence of incentives and no incentives).

\section{Introduction}

Fraud is one of the biggest threats in organizations and it can exist in organizations in both corporate sector and public sector. The Association of Certified Fraud Examiners (ACFE, 2018) states that asset misappropriation is a type of fraud that often occurs followed by corruption and the fraud of financial statements. In organizations of public sector, the type of fraud is dominated by corruption. Corruption is one of the most significant risks of fraud for organizations in various industries and in many regions. ACFE (2018) stated that in 2018 there were 2690 cases of frauds in 125 countries which 38\% cases were dominated by corruption cases. One of corruption cases that occurred in Indonesia was the case of Managing Director Karen Agustiawan of Pertamina who was allegedly implicated in the corruption case. The corruption was allegedly carried out in the form of the acquisition of assets owned by Roc Oil Company (ROC) in the Basker Gummy (BMG) Block Australia. The investigation made by the Attorney General's Office found that there were irregularities in the process of investment proposal in the BMG Block. It was suspected that the board of directors made a decision without the approval of the board of commissioners. State financial losses due to this case amounted to US $\$ 31,000,000$ and US\$26,000,000 or equivalent to Rp 568,000,000,000 (Suara.com, 2018).

The rampant corruption cases in public sector organizations in Indonesia have caused the Indonesian government to implement a policy regarding whistleblowing. Regulations regarding whistleblowing have long been regulated in the Act No. 13 of 2006 concerning Witnesses and Victims Protection. Near and Miceli (1995) stated that whistleblowing is used as a tool to prevent and eradicate deviant, illegitimate, ethical practices through the participation of employees and public who are actively reporting violations. Alleyne et al. (2013) stated that an important reason used by organizations related to the application of whistleblowing system is that whistleblowing system can be used by organizations as a strategy to improve and maintain the quality of organizations and to prevent irregularities to be more complicated. David (2011) stated that whistleblowing system requires employees to report various kinds of fraud occurring in their organization.

With the Act No. 13 of 2006 established by the government, whistleblowing system must be considered by organizations, so that the whistleblowing system can effectively increase employees' participation in reporting of fraud. The main problem in implementing of a whistleblowing system is the existence of employees' willingness to report a fraud. Suryono and Chariri (2016) revealed that various threats and risks can be received by a whistleblower which includes the risk of receiving threats of personal safety, shunned by colleagues, and risk of losing of a job position in an organization or even risk of being fired from a job. This condition can cause doubts for employees who want to realize their whistleblowing intention. Thus, whistleblowers need to get support and protection from their organizations. There have been many previous studies that discuss the factors that influence one's intention to do whistleblowing. Research by Utami et al. (2017) concluded that the reporting 
path factor and the reward method applied by an entity have interactions and causality relationships in generating whistleblower intentions to report fraud. Kurniawan et al. (2019) explains that organizational justice influences someone to have the intention of whistleblowing as well as personal cost of reporting and the status of wrongdoer Vinancia et al. (2019) as a factor that also influences someone to have whistleblowing intentions.

One of whistleblowing cases occurring in Indonesia is the case of "Papa Minta Saham" ("the father asks for shares") that implicated Setya Novanto in 2015. This case was triggered from the report of the Minister of Energy and Mineral Resources, Sudirman Said, who acted as the whistleblower, which he reported events related to the contract extension of PT Freeport Indonesia. Sudirman Said reported the events to the Honorary Council of People's House of Representative. In his explanation Sudirman reported that Setya Novanto requested 20 percent shares of corporate shares and requested a 49 percent shares on the Urumuka Hydroelectric Power Plant project in PT Freeport Indonesia by citing of names of President Joko Widodo and Vice President Jusuf Kalla in Setya Novanto's effort.

One of factors that influence individuals to perform whistleblowing is the trust towards leadership. Gao et al. (2011) states that leadership has an important role in improving and developing organizational roles. According to Robbins and Judge (2013) trust is a positive expectation or hope towards other people's words, actions, and policies. Simons (2002) stated that a leader that has integrity is the one whose actions describe his words. If someone is aware the existence of frauds or existence of activities that are not in line with the existing rules, he can report them to the leadership or to anyone who have the authority to receive reports and who can forward those reports to higher authorities for further processing. Trust in leadership will prompt employees to take risks and increase their commitment to their organization. results of research done by Palanski and Yammarino (2007) who conducted a review of various leadership integrity journals show that several studies used PLIS (Perceived Leader Integrity Scale) and BI (Behavioral Integrity) methods, and the result show that future research can use different methods. This study shows that trust in leadership requires strong integrity from leaders.

There are various whistleblowing studies that are associated with providing incentives. Gao and Brink (2017) investigated the effects of providing high amount incentives on individuals' behavior for risk taking. The results of that study indicate that high amount incentives will result a greater risk taking than low amount incentives. High amount incentives are usually given in the form of monetary or financial incentives. Organizational members or external parties are more likely to report frauds to higher authorities when they receive incentives in the form of cash or long-term work contracts. Therefore, incentive system has positive impacts on fraud reporting in organizations. Andon et al. (2018) examined whether monetary incentives that are provided by regulators can encourage individuals to undertake external whistleblowing. The results of his study indicate that monetary incentives can encourage external whistleblowing intentions.

Another study was conducted by Xu and Ziegenfuss (2008) which this study used internal auditors as experimental subjects to study the provision of incentives in the form of cash and long-term work contracts. The results of the study show a positive impact related to the effect of incentives provision to individuals who reveal frauds. Internal auditors are more likely to report fraud if there are incentives or rewards. In Indonesia, regulations regarding the provision of incentives have been regulated in Rules No. 48 of 2018 concerning Procedures for Community Participation and the Awarding of Prevention and Eradication of Corruption. The regulation explains that the government will provide incentives to members of organizations or the public if they report acts of corruption that they find.

The research results of Palanski and Yammarino (2007) on leadership integrity journals show that the behavior of leaders in an organization also can greatly influence their employees to perform whistleblowing. Another variable used in this study is the provision of incentives. Research on incentives carried out by Xu and Ziegenfuss (2008) and Brink et al. (2017) showed that incentives have positive impacts on individuals to perform whistleblowing which the type of incentives provided also influences one's decisions to take a whistleblowing action. For example giving of money is more effective than a promotion or a long-term work contract. Based on previous researches, there are no studies that study the interaction between the variable of trust in leadership and incentives for whistleblowing intentions. Thus, this study will examine further about trust in leadership in terms of leadership integrity. In addition, this study uses an experimental research design, whereas in previous studies only reviewed several leadership integrity journals such as the study of Palanski and Yammarino (2007). The aim of this study is to examine the causality relationship between provision of incentives and employees' trust in the leadership of their organization that will influence their decisions to perform whistleblowing. This study will hopefully can give more information in the audit field related to whistleblowing issue and provide empirical evidence of whistleblowing actions related to the effect of providing of incentives and employees' trust in the leadership of their company. 


\section{Literature Review}

\section{Theory of Planned Behavior (TPB)}

Lee et al. (2010) stated that the Theory of Planned Behavior (TPB) is an explanatory model that has been widely applied in studies of behavioral intentions. TPB stipulates that human behavior is initiated by the intention to carry out such behavior. Behavior intention is determined by three factors, namely, attitudes toward behavior, subjective norms, and control of behavior. Ajzen (1991) stated that when individuals see a behavior positively (i.e. attitudes), or predict someone will do a behavior (subjective norms), and believe that they can perform a behavior (control behavior), this functions as a direct determinant of the extent to which they are do a behavior. It can be said that an attitude is an overall evaluation of behavior done by an individual (Ferdous, 2010). Ajzen (1991)stated that the greater of factors supporting a person to conduct a behavior, the greater of behavior control and the greater of an inhibiting factor when he performs a behavior, then it encourages the person not to do such behavior.

There are many factors that influence whistleblowing intentions which one of them is the trust towards the integrity of the leadership and the provision of incentives that will encourage people to show their whistleblowing intentions. This is reflected in whistleblowing intentions owned by individuals who will consider the benefits derived from their whistleblowing actions. A person will show his whistleblowing intention if he knows by receiving incentives he can have benefits from his whistleblowing action. Another factor that influences behavioral intention is the subjective norms, such as social pressure that influences someone to take an action. In this study, if someone has confidence in the leadership of his company, the potential is greater for him to show his whistleblowing intention. The last factor that influences behavioral intention is the behavioral controls which there are several factors that reinforcing or weaken one's intention to engage in whistleblowing actions. A reinforcing factor for whistleblowing intentions is the provision of incentives. A person will act as a whistleblower when he has positive perceptions, beliefs and attitudes that what he does in the whistleblowing process is well-intentioned and acceptable to the surrounding environment.

\section{Whistleblowing Intention}

Whistleblowing is a disclosure of illegal practices, frauds, deviant actions, or unauthorized activities by a member of an organization under supervisor's policy to various parties who can follow-up this action (Near \& Miceli, 1995). According to Alleyne et al. (2013) whistleblowing in the realm of auditing is reporting on actions that are considered unethical, where someone does the reporting through existing reporting channels, whether accompanied by the reporter's identity or not. The emergence of whistleblowing is motivated by the existence of four elements, namely the existence of a person who reports (whistleblower), there is a complaint regarding the occurrence of violations or actions that are not ethically appropriate, generally an organization or group consisting of a group of individuals committed to committing an act of violation or not according to ethics, and the existence of other parties who received the complaint or report (Dasgupta \& Kesharwani, 2010). Whistleblowing can also be defined as issuing a dissent in general, which can be directed both externally and internally (Taylor \& Curtis, 2013). Members of an organization can report frauds to the organization or can report the frauds to public by delivering information that they have (Gökçe, 2013). The act of an employee who reports a fraud to management or authorities in his organization is called internal whistleblowing. Meanwhile, external whistleblowing happens when an employee reports a fraud occurring within his organization to the parties outside of the organization or to the law enforcement officers because the fraud is considered to cause harm to the public.

Susmanschi (2011) added that the whistleblower phenomenon arises when there are reports of employees suspected of making mistakes at work that need to be followed up by making disclosures in the public interest. Jeon (2017) revealed that whistleblowers play an important role in opening up unethical behavior in government and making government more transparent and accountable to the public. Lee et al. (2010) said that an intention is the will to achieve a goal. Intention will be realized through an action that is done at the right time and at the right opportunity. Winardi (2013) states that a whistleblowing intention is needed to realize a whistleblowing action. The purpose of implementing of whistleblowing will not be able to be achieved without one's intention to report frauds.

\section{Trust in Leadership}

According to Robbins and Judge (2013) trust is a positive expectation or hope towards other people's words, actions, and policies. According to Gao et al. (2011) trust can be interpreted as a willingness to take risks and the level of trust is an indication of the amount of risk that is willing to be taken. Flores and Solomon (1998) found that trust arises because there are people who can be trusted. Trust is a belief in the integrity or reliability of others (Janasz et al., 2014). According to Zahra (2011) integrity is a commitment to do everything according to 
the existing ethical rules, values and norms and it contains a consistency to keep doing that commitment. Simons (2002) stated that a leader who has integrity is a leader whose actions describe his words. Trust in leadership will create positive results on attitudes, such as commitment towards a company and good performance of employees. When an employee trusts in the leadership of his organization, he will automatically commit to the organization. The lower of one's trust towards the leadership of an organization the greater chance of him to act erroneously.

\section{Incentives}

Incentive is another type of provision of remuneration or salary which is not based on job evaluation but it is based on work performance (Hasibuan, 2012). Swasto (2011) stated that an incentive is a bonus payment besides a wage or a salary received by an employee because his work performance exceeds the specified work standards. Wibowo (2018) states that incentives are generally carried out as a strategy to improve agency productivity and efficiency by utilizing the behavior of employees who have a tendency to work improperly or not optimally. Types of incentives are divided into two groups, namely, material incentives and non-material incentives (Sarwoto, 2010). Material incentive is an incentive given to employees in the form of money. While non-material incentives are incentives that are given to employees not in the form of money such as promotions, long-term employment contracts, or other gifts. The system of providing incentives contains the policies, processes and activities of an organization to reward employees according to their abilities, contributions and intelligences. Xu and Ziegenfuss (2008) stated that the reward system has a great impact on organizations to retain and motivate high-potential members to get their high level of performances. Members of an organization will tend to perform more whistleblowing if they obtain incentives. Stikeleather (2016) states that the intention of company employees to report fraud will also increase when they are offered monetary gifts.

The provision of incentives is regulated in the Law No 43/2018 on the procedures for implementing public participation and giving rewards in the prevention and eradication of criminal acts of corruption. The Law No 43/2018 of article 13 paragraph (1) states that "Those who have contributed to the prevention, eradication, or disclosure of corruption are eligible to obtain awards". The Law No 43/2018 of article 13 paragraph (3) states that awards are given in the form of certificates and/or premiums. Incentives provided either in the form of material and non-material incentives. The Law No 43/2018 of article 17 paragraph (1) states that "In the event related to the results of the assessment referred to Article 15 are agreed that awards can be given in the form of premiums which the amount of the granted premiums is $2 \%$ (two per million) of the total state financial losses that can be returned to the state". The Act No 43/2018 of article 17 paragraph (2) states "The amount of premiums that are given as referred to paragraph (1) is at most Rp 200,000,000.00 (two hundred million rupiahs). Through the enactment of governmental regulation No. 43 of 2018, it is expected that all elements of Indonesian societies can play their active roles in eradicating the acts of corruption by reporting those acts that they find.

\section{Formulation of Hypotheses}

\section{Relationship between Trust in Leadership and Whistleblowing Intentions}

In previous studies, research on trust in leadership was also carried out by Palanski and Yammarino (2007) who conducted reviews in various leadership integrity journals. Flores and Solomon (2015) stated that trust arises because there are people who can be trusted. Trust in superiors will lead attitudes such as commitment to a company (Dirks \& Ferrin, 2002). When an employee has more trust in his superior, he will automatically commit to his company.

Everyone will first analyze the impact that can occur when he/she takes a whistleblowing action and he/she will evaluate his/her level of trust in the leadership related to his/her whistleblowing action (Liu et al., 2015). The result of research shows that the lower level of an employee's confidence in the leadership of his organization the higher chance of the employee to make deviant actions. Conversely, the result of research shows that the higher trust towards the leadership, the higher one's intention to show one's whistleblowing intention. Based on the arguments and results of previous studies, the first hypothesis can be formulated as follows:

H1: Subjects in condition of high trust will have higher whistleblowing intentions than subjects in condition of low trust in the leadership.

\section{Relationship between Incentives and Whistleblowing Intentions}

Several previous studies have proven that providing incentives will positively influence a person's intentions to perform whistleblowing. Xu and Ziegenfuss (2008) conducted a study by performing an experiment using 201 internal auditors as subjects of research to test the provision of incentives that may affect a person's intention to do whistleblowing. The results of the study show that the incentive system has positive impacts and it shows that internal auditors are more likely to report frauds to higher authorities when they get incentives. In another study, Andon et al. (2018) conducted a study using 80 professional accountants as subjects of the research which show 
that the provision of monetary incentives have positive effects on whistleblowing intentions. Rose et al., (2016) in their research found that the amount of the rewards or incentives affect whistleblowing intention and motivate employees to perform whistleblowing.

Providing incentives in the form of incentives or rewards can be an incentive or motivation for individuals to reveal frauds in their organization. People will be enthusiastic to report frauds that they find if they obtain incentives or rewards. Thus, the more incentives provided the higher individuals' intention to do whistleblowing. Based on the arguments and results of previous studies, the second hypothesis can be formulated as follows:

H2: Subjects in the incentive system have higher whistleblowing intentions than subjects in the non-incentive system.

\section{Relationship between Trust in Leadership and Incentives in Whistleblowing Intentions}

Flores and Solomon (2015) stated that trust arises because there are people who can be trusted. Trust is a belief in the integrity or reliability of others (Janasz et al., 2014). Trust in leadership can influence individuals in their decision making related to whistleblowing intentions. The higher an individual's level of trust is in the leadership, the higher probability for the individual to have a whistleblowing intention, when the individual finds of actions deviating from the applicable rules. People will feel more safe and confident to carry out their whistleblowing intentions when they have high trust in the leadership of their organization.

Providing high incentives will prompt members of an organization to have high whistleblowing intentions. Gao and Brink (2017) stated in his research that members of an organization are more likely to report frauds that they find to someone in higher authority in their organization when they get incentives or rewards. People will tend to report a fraud if they get a reward or incentive for reporting a fraud. On the other hand, people will not report a fraud if they do not get a reward or incentive for reporting a fraud. Based on this argument, the third hypothesis can be formulated as follows:

H3: There is an interaction between trust in leadership and incentives for whistleblowing intentions.

\section{Research Methods}

\section{Research Design}

This study is a quantitative type of study and $2 \times 2$ experimental between subjects is used as the design of the study. This study uses trust in leadership and incentives as the dependent variables, while whistleblowing intention is used as the independent variable. The dependent variables are manipulated with cases in experimental module. Whistleblowing intention as independent variable is measured with Likert Scale $10-100$. The data used are primary data taken directly from the subjects of this study. The subjects of this study were the undergraduate students of Economics and Business Faculty of Universitas Kristen Satya Wacana who took the audit of information system as their major course. Carini et al. (2003) stated that college students as respondents will be able to detect and analyze things well than other respondents. One of previous studies that used students as experimental subjects was the study done by Firmansyah and Wrastari (2014). Students who took information system audit course were considered to have understood auditing because the subjects had taken the auditing course in the previous semester. With their understanding about auditing, students were expected to be able to provide appropriate evaluations of whistleblowing intentions.

\section{Experimental Procedure}

In this study, the subjects played the role as employees of the Supreme Audit Board, which were tasked to examine the management and responsibilities of state finances. The subjects were faced with a fraud occurring at the Board. The fraud was in the form of a bribery received by the head of the auditor team from the client to falsify the audit findings.

At the first stage, all subjects were divided into 4 groups randomly. At the second stage, the subjects who had been included in groups were further divided into classes based on modules with different treatments. At the third step, each subject received one module. The division of modules was based on groups that the subjects received. Group 1 received a treatment of high trust in the leadership and given incentives. Group 2 received a treatment of high trust in the leadership and given no incentives. Group 3 received a treatment of low trust in the leadership and given incentives. Meanwhile, group 4 received a treatment of low trust in the leadership and given no incentives. At the fourth stage, subjects were asked to fill out their personal data, including: gender, age, grade point average, and semester. Filling out this personal data aims to test demographics that might affect the subjects in their decision making.

At the fifth stage, after the subjects read the experimental rules, they were given several general questions related to the audit field since whistleblowing intention is one of the material learned in the audit course. At the 
sixth step, the subjects were given information about the roles and conditions that must be encountered by subjects which they were asked to answer questions of manipulation related to the roles and conditions faced by the subjects. The subjects acted as the auditor staffs who were aware of the existence of fraud in their workplace. Manipulations that were provided are: high level of trust in the leadership; low level of trust in the leadership; granting of incentives; and no granting of incentives). In addition, the subjects were given questions of manipulations related to their decision making. At the seventh stage, modules that had been filled out were collected. At the last stage, debriefing was held with an aim to restore all subjects' conditions to their original states.

\section{Obligations and Procedures of Experiments}

Subjects were divided into four groups randomly who received different treatment in each group, namely, high level of trust in the leadership, low level of trust in the leadership, granting of incentives, and no granting of incentives. The matrix of the experimental research design is explained in Table 1.

Table 1. Experimental Matrix of the Study

\begin{tabular}{lccc}
\hline \multirow{2}{*}{ Whistleblowing Intention } & \multicolumn{2}{c}{ Incentives } \\
\cline { 2 - 4 } Trust in Leadership & High & Group 1 & No \\
& Low & Group 3 & Group 2 \\
& Soup 4 \\
\hline
\end{tabular}

Notes: Group 1 - trust in leadership is high and there are incentives, Group 2 - trust in leadership is high and there are no incentives, Group 3 - trust in leadership is low and there are incentives, Group 4 - Trust in leadership is low and there are no incentives.

Source: Data Processed

\section{Analysis Techniques}

This study uses a test stage for checking of manipulation that aims to determine whether subjects pass the checking of manipulation. The next stage is descriptive test of subjects and test of effectiveness of randomization using One Way Analysis of Variance (ANOVA). Randomization test aims to determine whether characteristics of the subjects influence subjects' decision making to do whistleblowing. The test of the first and second hypothesis was done using the mean difference test (independent t-test). The test of the third hypothesis is done using TwoWay Anova to see whether there is an interaction between two independent variables.

\section{Results and Discussion}

\section{Overview of the Study}

Experiments were held at the Faculty of Economics and Business of Universitas Kristen Satya Wacana to students who were taking the course of information system audit. Participants who were involved in this study consisted of 115 students that were divided into 4 groups. There were 99 students who received the treatments and passed 3 manipulation questions regarding roles, tasks and manipulation questions related to considerations of decision making. Demographic characteristics of the subjects in this study i.e. gender, age, grade point average and semester index that can be seen in Table 2 .

Table 2. Characteristics of Participants

\begin{tabular}{llcc}
\hline \multicolumn{2}{c}{ Demographic Characteristics } & Number of Participants & Percentage (\%) \\
\hline \multirow{2}{*}{ Gender } & Male & 25 & 25.3 \\
& Female & 74 & 74.7 \\
\multirow{4}{*}{ Age } & 19 & 1 & 1 \\
& 20 & 28 & 28.3 \\
\multirow{4}{*}{ Grade Point Aveerage } & 21 & 62 & 62.6 \\
& 22 & 8 & 8.1 \\
\multirow{2}{*}{ Semester } & $2,50-2,99$ & 7 & 7.1 \\
& $>3.50$ & 62 & 62.6 \\
\hline
\end{tabular}

Source: Data Processed 
Table 2 shows that the demographic characteristics of the participants varied considerably. $74.7 \%$ of participants in this study were female. The participants were 19 to 22 years old with most participants were 21 years by $62.6 \%$. The majority of participants in this study were studying at semester 3 of the 2018/2019 school year and most participants had grade point average at 3.00 to 3.49 GPA.

\section{Checking of Manipulation}

Manipulations of trust in the leadership and incentives were carried out through the comprehension test on the roles and conditions faced by the subjects in this study. The subjects were given a number of pretest questions related to information on each provided manipulation. Each subject of this study would be declared as qualified if he/she could answer at least 2 out of 3 questions correctly. In this study, there were 99 subjects who had passed the manipulation tests. 11 subjects answered 2 questions correctly and 88 subjects answered 3 questions correctly.

Based on the results of the manipulation checking, all subjects had received manipulation treatments in accordance with the trust in leadership and incentives. These results can be used for further tests.

\section{Test of Randomization}

In an experimental study, it is necessary to start the study by checking the statistics to ensure the effectiveness of randomization. A randomization can be declared as effective if there is no influence of demographic characteristics on subject's decision making. In this study, the randomization test was carried out using the One Way ANOVA test, and the results of this test can be seen in Table 3.

Table 3. Results of Randomization Test of Demographic Characteristics

\begin{tabular}{llccc}
\hline & & Mean Square & Sig. & Information \\
\hline Gender & Between Groups & 0,172 & & No Influence \\
& Within Groups & 0,192 & 0,525 & \\
Age & Between Groups & 0,060 & & No influence \\
& Within Groups & 0,385 & 0,996 & \\
Grade Point Average & Between Groups & 0,347 & & No Influence \\
& Within Groups & 0,321 & 0,384 & \\
Semester & Between Groups & 0,027 & & \multirow{2}{*}{ No Influence } \\
& Within Groups & 0,030 & 0,523 & \\
\hline
\end{tabular}

Source: Data Processed

Based on the test results of the effectiveness of randomization in table 3, there is no influence of demographic characteristics in terms of gender, age, grade point average, and semester on the evaluation of whistleblowing intentions. This is indicated by the significance level of all demographic characteristic variables which are above 0.05 . So, it can be concluded that the results of inter-cell research in this study will actually be due to the manipulation given to each cell and not because of the influence of the demographic characteristics of the subjects of the study.

\section{Test of Hypothesis 1}

\section{Relationship between Trust in Leadership and Whistleblowing Intention}

Hypothesis 1 of this study states that subjects in the condition of high-level trust in leadership will have higher whistleblowing intentions than subjects in the condition of low-level trust in leadership. Test of hypothesis 1 was done using Sample T-test with one population consisting of group 1 and group 2 receiving the treatment of high trust in leadership, and group 3 and group 4 receiving trust treatment of low trust in leadership.

Table 4. Test Results of Hypothesis 1

\begin{tabular}{lllccc}
\hline & & Mean & Std Deviation & $t$ & Sig. (2-tailed) \\
\hline \multirow{2}{*}{ Trust in Leadership } & High & 77,64 & 10,31 & & \\
& Low & 33,12 & 9,9 & 21,86 & 0,000 \\
\hline
\end{tabular}

Source: Data Processed

Table 4 shows that the average potential for whistleblowing intention in the treatment of high-level trust in leadership is 77.64 while in the treatment of low-level trust in leadership is 33.12. Statistical test results show 
the value of Sig (2-tailed) equal variances that is assumed in the t-test for Equality of Means is 0,000 which is smaller than alpha (0.05). So, it can be concluded that it is significant at the $5 \%$ probability level. The test results show that the potential for whistleblowing intention is greater in the condition of a high level of trust in leadership than whistleblowing intention in the condition of low level of trust in leadership.

Flores and Solomon (2015) stated that trust arises because there are people who can be trusted. Simons (2002) stated that a leader who has integrity is the leader whose actions describe his words. When employees have good information about leaders (senior management) they will tend to have high trust in the leaders. Dirks and Ferrin (2002) in their research stated that trust in the leadership will lead to positive attitudes such as commitment to a company. When employees believe in the integrity of their leaders they will have confidence in their leaders, and in turn they will have a commitment to the company. When employees find any deviant actions that are not in accordance with the policy of the company, the employees will report the action to the leaders because they believe that the leaders will be able to eradicate and correct the deviant actions.

\section{Test of Hypothesis 2}

\section{Relationship between Incentives and Whistleblowing Intentions}

Hypothesis 2 in this study states that subjects in the presence of incentives will have higher whistleblowing intentions than subjects in the absence of incentives. Test of hypothesis 2 was done using Sample T-test with one population consisting of group 1 and group 2 that received a treatment with incentives, and group 3 and group 4 that received a treatment without any incentives.

Table 5. Test Results of Hypothesis 2

\begin{tabular}{lccccc}
\hline & & Mean & Std Deviation & T & Sig. (2-tailed) \\
\hline Incentives & Yes & 68,65 & 14,55 & 13,87 & \\
& No & 33,40 & 10,05 & 14,12 & 0,000 \\
\hline
\end{tabular}

Source: Data Processed

Table 5 shows that the average potential for whistleblowing intentions for group that receive a treatment with incentives is 68.65 while group that receive a treatment without any incentives is 33.40. Statistical test results show that the value of Sig (2-tailed) equal variances that is assumed in the t-test for Equality of Means is 0,000 which is smaller than alpha (0.05). So, it can be concluded that it is significant at the $5 \%$ probability level. The test results show that the potential for whistleblowing intentions are even greater with incentives compared to whistleblowing intentions without any incentives.

Xu and Ziegenfuss (2008) stated that the incentives system has a great impact on organizations to retain and motivate their high-potential members to get a high level of performance. The results of this study are in line with the study conducted by Gao and Brink (2017) who found that the provision of incentives influenced individuals to make their decisions. When employees find frauds in their organization, they will tend to report the frauds to the higher authorities if they can get incentives. Thus, providing of incentives can motivate employees to reveal frauds in their organization. So, it can be concluded that the more incentives are given, the greater potential for individuals to have whistleblowing intentions.

\section{Test of Hypothesis 3}

\section{Interaction between Trust in Leadership and Incentives for Whistleblowing Intentions}

The test results of Hypothesis 1 and Hypothesis 2 show that the two independent variables, namely, trust in the leadership and incentives show significant results that influence whistleblowing intentions. Hypothesis 3 states that there is an interaction between the two independent variables on whistleblowing intentions and to test it, the Two Way Anova test can be used to compare the mean differences among groups that have been grouped based on independent variables.

Table 6. Test Results of Between Subject Effects on Hypothesis 3 Data

\begin{tabular}{lcc}
\hline \multicolumn{1}{c}{ Source } & Mean Square & Sig. \\
\hline Corrected Model & 10772,315 & 0,000 \\
Intercept & 370242,776 & 0,000 \\
Trust in Leadership & 22715,596 & 0,000 \\
Incentives & 7856,836 & 0,000 \\
Trust in Leadership*Incentives & 2455,456 & 0,000 \\
\hline
\end{tabular}

Source: Data Processed 
Based on the test results presented in table 6, it shows that all independent variables, namely, trust in the leadership and incentives significantly influence the dependent variable, so that the model is declared as valid. The Intercept Model shows that the value of Sig is 0,000 which is smaller than alpha (0.05), which means that without the influence of the independent variable, the value of the dependent variable can change.

Trust in the leadership and incentive variables show a significant influence on whistleblowing intentions. The variable of trust in leadership shows significance at 0,000, and the variable of incentives also show significance at 0,000. Significance value of 0,000 which is smaller than alpha at 0.05 proves that there is an influence of the dependent variable on whistleblowing intentions. Thus, the first and second hypotheses can be accepted. Interaction of trust in the leadership and incentives shows a significance value of 0,000 which is smaller than alpha at 0.05 . Thus, it can be concluded that the interaction between trust in the leadership and incentives significantly influences whistleblowing intentions. The interaction of trust in the leadership and incentives is illustrated in Figure 1.

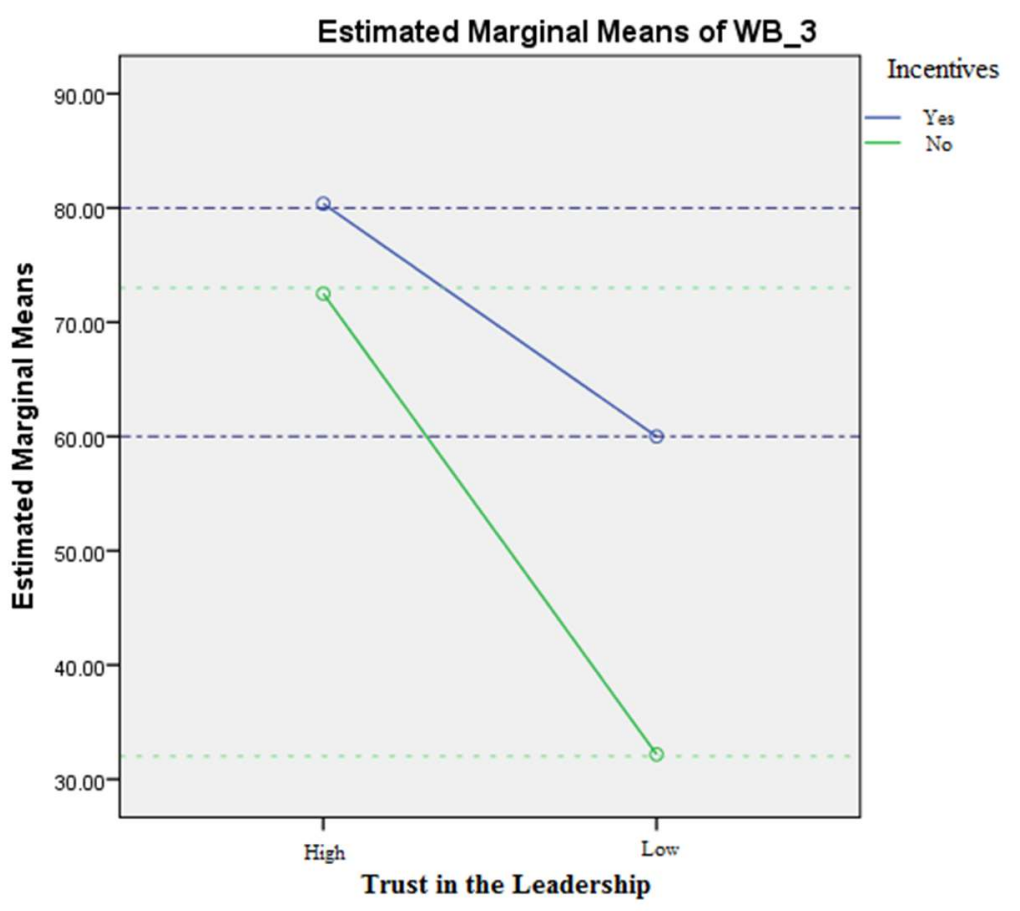

Figure 1. Trust in Leaders and Incentives in Whistleblowing Intentions

It can be seen in Figure 1 that the first group, which is in the condition of high-level trust towards the leadership and incentives, is at the point of estimated marginal means of 80.00 and this group is at the highest position compared to the other three conditions. The second group, which is in the condition of high level of trust in the leadership and no incentives, is at the point of estimated marginal means above 70.00. The third group, which is in the condition of low level of trust in the leadership and incentives, is at the estimated marginal means of 60.00. The fourth group, which is in the condition of low trust in the leadership and no incentive, is at the point of the lowest estimated marginal means at below of 40.00 compared to the other three conditions.

This study shows that there is an interaction between trust in the leadership and the provision of incentives. Whistleblowing intentions are affected by the high level of trust in the leadership which the trust encourages employees to be more committed to their organization and providing of incentives encourages employees to have whistleblowing intentions when they find any deviant actions or frauds. Gao and Brink (2017) in their research found that members of an organization are more likely to report frauds that they find to higher authorities in the organization when they get incentives or rewards. When an employee has a goal to advance his organization, he will tend to report any actions deviating from the existing rules, although the whistleblowing action contains risks for the reporter in the present or future time.

\section{Conclusions}

This study examines the effect of trust in the leadership and incentives toward whistleblowing intentions using an experimental study. The analysis shows that, firstly, trust in the leadership significantly influences whistleblowing intentions. The greater whistleblower's trust in the leadership, the greater his intention to perform 
whistleblowing. Individuals who have high trust in the leadership, they will be committed to their organization. Individuals who are aware of an action that deviates from the rules of their organization, they will report it to the higher authorities hoping that the higher authorities will be able to stop and correct the action. On the other hand, those who have low level of trust in the leadership, their commitment to the organization are also low that in turn their whistleblowing intentions are low. Thus, the potential for individuals to show their whistleblowing intentions are greater when they have high trust in the leadership than those who are in the condition of low level of trust in the leadership.

Secondly, provision of incentives has a significant effect on whistleblowing intentions. The potential for whistleblowers to undertake whistleblowing actions is greater if they are given incentives when they see an action deviating from the rules of their organization. Providing incentives can be a motivation for whistleblowers to do whistleblowing when they find frauds. Conversely, no incentives for whistleblowers will reduce their intentions to perform whistleblowing actions.

Thirdly, there is an interaction between trust in the leadership and incentives for whistleblowing intentions. This happens because trust in the leadership and provision of incentives can influence individuals to perform whistleblowing. When individuals have high commitment to an organization, they will try to advance their organization, including by reporting any frauds that they can find. Providing incentives also affects individuals' whistleblowing intentions that in turn it makes them to be more motivated to have whistleblowing intentions.

The limitation of this study is that the situation was not conducive for conducting of experiments that caused several respondents made mistakes in filling out the modules because they did not follow the tutor's instructions properly. The limitations of this study are expected to be a reference for other researchers for further research in the future. Future studies are expected to be better for experimental tutors in directing their research subjects so that there will be no unexpected things in future studies and also new variables can be added in the future studies.

\section{References}

ACFE. (2018). Report to the Nations 2018 Global Study on Occupational Fraud and Abuse. https://www.acfe.com/uploadedFiles/ACFE_Website/Content/rttn/2018/RTTN-Asia-Pacific-Edition.pdf

Ajzen, I. (1991). The theory of planned behavior. Organizational Behavior and Human Decision Processes, 50(2), 179-211.

Alleyne, P., Hudaib, M., \& Pike, R. (2013). Towards a conceptual model of whistle-blowing intentions among external auditors. The British Accounting Review, 45(1), 10-23.

Andon, P., Free, C., Jidin, R., Monroe, G. S., \& Turner, M. J. (2018). The impact of financial incentives and perceptions of seriousness on whistleblowing intention. Journal of Business Ethics, 151(1), 165-178. https://doi.org/10.1007/s10551-016-3215-6

Brink, A. G., Hobson, J. L., \& Stevens, D. E. (2017). The effect of high power financial incentives on excessive risk-taking behavior: An experimental examination. Journal of Management Accounting Research, 29(1), $13-29$.

Carini, R. M., Hayek, J. C., Kuh, G. D., Kennedy, J. M., \& Ouimet, J. A. (2003). College student responses to web and paper surveys: Does mode matter. Research in Higher Education, 44(1), 1-19. https://doi.org/10.1023/A:1021363527731

Dasgupta, S., \& Kesharwani, A. (2010). Whistleblowing: A survey of literature. The IUP Journal of Corporate Governance, 9(4), 57-70.

David, F. R. (2011). Strategic Management Concepts and Cases (13th ed.). Prentice-Hall.

Dirks, K. T., \& Ferrin, D. L. (2002). Trust in leadership: Meta-analytic findings and implications for research and practice. Journal of Applied Psychology, 87(4), 611-628. https://doi.org/10.1037/0021-9010.87.4.611

Ferdous, A. S. (2010). Applying the theory of planned behavior to explain marketing managers' perspectives on sustainable marketing. Journal of International Consumer Marketing, 22(4), 313-325.

Firmansyah, R. A., \& Wrastari, A. T. (2014). Pengaruh penggunaan film sebagai media belajar terhadap pencapaian Higher Order Thinking Skill pada mahasiswa fakultas psikologi UNAIR. Jurnal Psikologi Klinis Dan Kesehatan Mental, 3(1), 40-47. https://doi.org/10.1002/ejoc.201200111

Flores, F., \& Solomon, R. C. (1998). Creating trust. Business Ethics Quarterly, 8(2), 205-232. https://doi.org/10.1017/S1052150X0000381X 
Gao, Lei, \& Brink, A. G. (2017). Whistleblowing studies in accounting research: A review of experimental studies on the determinants of whistleblowing. Journal of Accounting Literature, 38, 1-13.

Gao, Liping, Janssen, O., \& Shi, K. (2011). Leader trust and employee voice: The moderating role of empowering leader behaviors. The Leadership Quarterly, 22(4), 787-798.

Gökçe, A. T. (2013). Prospective teachers' attitudes toward whistle-blowing according to type of intelligence. Mediterranean Journal of Social Sciences, 4(4), 11-23.

Hasibuan, M. (2012). Manajemen Sumber Daya Manusia. PT. Bumi Aksara.

Janasz, S. de, Dowd, K., \& Schneider, B. (2014). Interpersonal Skills in Organizations (5th ed.). McGraw-Hill Education.

Jeon, S. H. (2017). Where to report wrongdoings? Exploring the determinants of internal versus external whistleblowing. Journal International Review of Public Administration, 22(2), 153-171.

Kurniawan, A., Utami, I., \& Pesudo, D. A. C. A. (2019). Organizational justice and whistleblowing: An experimental test. Jurnal Akuntansi Dan Keuangan, 20(2), 73. https://doi.org/10.9744/jak.20.2.73-78

Lee, J., Cerreto, F. A., \& Lee, J. (2010). Theory of planned behavior and teachers' decisions regarding use of educational technology. Journal of Educational Technology \& Society, 13(1), 152-164.

Liu, S., Liao, J., \& Wei, H. (2015). Authentic leadership and whistleblowing: Mediating roles of psychological safety and personal identification. Journal of Business Ethics, 131, 107-119. https://doi.org/10.1007/s10551-014-2271-z

Near, J. P., \& Miceli, M. P. (1995). Effective-whistle blowing. Academy of Management Review, 20(3), 679-708.

Palanski, M. E., \& Yammarino, F. J. (2007). Integrity and leadership:. Clearing the conceptual confusion. European Management Journal, 25(3), 171-184. https://doi.org/10.1016/j.emj.2007.04.006

Robbins, S. P., \& Judge, T. A. (2013). Organizational Behaviour Individuals (15th ed.). Pearson.

Rose, J. M., Brink, A. G., \& Norman, C. S. (2018). The effects of compensation structures and monetary rewards on managers' decisions to blow the whistle. Journal of Business Ethics, 150(3), 853-862. https://doi.org/10.1007/s10551-016-3222-7

Sarwoto. (2010). Dasar-Dasar Organisasi dan Manajemen. Ghalia Indonesia.

Simons, T. (2002). Behavioral Integrity: The Perceived Alignment Between Managers' Words and Deeds as a Research Focus. Organization Science, 13(1), 18-35. https://doi.org/10.1287/orsc.13.1.18.543

Simons, T. L. (2002). The perceived alignment between managers' words and deeds as a research focus (No. 22002; The Scholarly Commons).

Stikeleather, B. (2016). When do employers benefit from offering workers a financial reward for reporting internal misconduct? Accounting Organizations and Society, 52, 1-14.

Suara.com. (2018, September 24). Resmi Ditahan, Eks Dirut Pertamina Karen Agustiawan Menangis. Suara.Com. https://www.suara.com/news/2018/09/24/172104/resmi-ditahan-eks-dirut-pertamina-karen-agustiawanmenangis\#: :text=Resmi Ditahan\%2C Eks Dirut Pertamina Karen Agustiawan Menangis,-\%22Saya sebagai Dirut\&text=Mantan orang nomor satu di,merah muda bertuliskan Kejaksaan Agung.

Suryono, E., \& Chariri, A. (2016). Sikap , norma subjektif, dan intensi pegawai negeri sipil untuk mengadukan pelanggaran (whistle blowing). Jurnal Akuntansi Dan Keuangan Indonesia, 13(1), 102-116.

Susmanschi, G. (2011). Internal audit and whistle-blowing. Journal of Academic Research in Economics, 3(3), 636-640.

Swasto, B. (2011). Manajemen sumber daya manusia. UB Press. https://doi.org/10.35673/ajmpi.v9i2.429

Taylor, E. Z., \& Curtis, M. B. (2013). Whistleblowing in audit firms: Organizational response and power distance. Behavioral Research in Accounting, 25(2), 21-43.

Republik Indonesia. 2006. UU Nomor 13 Tahun 2006 Tentang Perlindungan Saksi Dan Korban. Sekretariat Negara. Jakarta.

Utami, I., Jori, A., \& Hapsari, A. N. S. (2017). Sudikah akuntan mengungkap aib kecurangan? Jurnal Akuntansi 
Multiparadigma, 8(3), 458-469.

Vinancia, C., Utami, I., \& Mohamed, N. (2019). Personal cost of reporting and status of wrongdoer: experimental study pf whistleblowing intention. Asia-Pacific Management Accounting Journal, 14(3), 81-103.

Wibowo. (2018). Manajemen Kinerja (10th ed.). Raja Grafindo Persada.

Winardi, R. D. (2013). The influence of individual and situational factors on lower-lavel civil servants' whislteblowing intention in Indonesia. Journal of Indonesian Economy and Business, 28(3), 361 - 376.

Xu, Y., \& Ziegenfuss, D. E. (2008). Reward systems, moral reasoning, and internal auditors' reporting wrongdoing. Journal of Business and Psychology, 22(4), 323-331. https://doi.org/10.1007/s10869-0089072-2

Zahra, E. (2011). Pengaruh integritas, kompetensi dan loyalitas kepemimpinan terhadap kepercayaan para bawahan di SBU perkapalan PT PUSRI Palembang. Jurnal Ilmiah Orasi Bisnis Politeknik Negeri Surabaya, VI, 122-132. 